\title{
Botanical formulations for the ecological management of Myzus persicae (Sulzer) and Aphis gossypii (Clover) (Hemiptera: Aphididae) and their side effects on parasitoids
}

\author{
Formulados botánicos para el manejo sustentable de Myzus persicae (Sulzer) y Aphis \\ gossypii (Clover) (Hemiptera: Aphidiae) y sus efectos secundarios en parasitoides
}

Jorge Castresana $^{1}$; Laura Puhl ${ }^{2}$

\begin{tabular}{l}
\hline \multicolumn{2}{c}{ ARTICLE DATA } \\
\hline 1 Researcher, Estación Experimental Agropecuaria \\
INTA Concordia, Concordia, Argentina, castresana. \\
jorge@inta.gob.ar \\
2 Researcher, Quantitative Methods Department, \\
Universidad de Buenos Aires, Buenos Aires, \\
Argentina, castresana.jorge@inta.gob.ar \\
\hline
\end{tabular}

Cite: Castresana, J.; Puhl, L. (2021). Botanical formulations for the ecological management of Myzus persicae (Sulzer) and Aphis gossypii (Clover) (Hemiptera: Aphididae) and their side effects on parasitoids. Revista de Ciencias Agrícolas. 38(1): 50-61 doi: https://doi.org/10.22267/rcia.213801.144

\section{Received: November 172020.}

Accepted: Jun 042021.
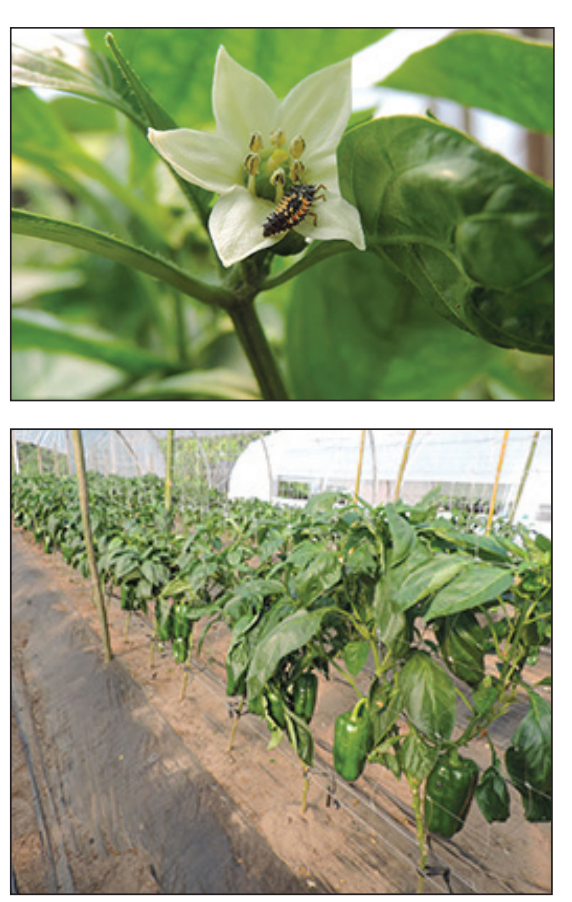

\section{ABSTRACT}

The peach aphid Myzus persicae (Sulzer) and cotton aphid Aphis gossypii (Clover) (Hemiptera: Aphididae) are considered to be key pests affecting greenhouse pepper crops in Argentina as a result of their frequent occurrence and the seriousness of the damage caused by their feeding behavior and the transmission of virus. The goal of this research was to determine the efficiency of botanical products to control aphids and their side effects on parasitoids in this crop. Thus, three biorational pest control formulations derived from essential oils (E0) and plant extracts (Es) were tested, namely (i) neem EO, cinnamon E0, clove EO, oregano EO and American marigold EO (formulation 1); (ii) garlic EO and cinnamon EO (formulation 2); (iii) garlic E and rue E (formulation 3); and a soy lecithin adjuvant (lecithin), and finally, a control (water spray method). For this research, a completely randomized design was replicated 3 times. These treatments were applied directly to the foliage by means of a backpack sprayer on a weekly basis until the end of this trial. Subsequently, the total number of healthy aphids and parasitized aphids (mummies) on every leaf was recorder in the field and in the laboratory analyzed thorough repeated measures. Analysis of Variance (ANOVA) and LSD Fisher method. The results showed that formulation 1 and formulation 3 recorded a lower number of aphids and mummies compared to the other treatments. This evidence would demonstrate that these formulations repel aphids and parasitoids without the lethal effects caused by the use of broad spectrum insecticides.

Key words: aphids; extracts; essential oils; parasitoids.

\section{RESUMEN}

Los pulgones del duraznero Myzus persicae y del algodonero Aphis gossypii (Hemiptera; Aphidiae) son plagas claves en el cultivo de pimiento protegido en Argentina debido a su frecuente aparición y la magnitud de los daños ocasionados por la alimentación y la transmisión de virus. El objetivo del trabajo fue determinar la eficacia de productos botánicos 
para controlar esta plaga y sus efectos secundarios en parasitoides en este cultivo. Para ello, fueron evaluados tres formulados de origen botánico para control de plagas derivados de aceites esenciales (AEs) y extractos vegetales (Es), a saber: (i) aceite esencial (AE) de neem, $\mathrm{AE}$ canela, $\mathrm{AE}$ clavo de olor y combinaciones: $\mathrm{AE}$ orégano y AE de copete (formulado 1); (ii) AE de ajo y AE de canela (formulado 2); (iii) extracto (E) de ajo y E de ruda (formulado 3); una coadyuvante lecitina de soja (lecitina) y, una pulverización con agua (control). Para este estudio se efectuó un diseño totalmente aleatorizado con tres repeticiones. Los tratamientos fueron aplicados directamente sobre el follaje con mochila manual semanalmente hasta concluir el estudio. Posteriormente, se evaluó el número de pulgones sanos y parasitados (momias) por hoja en campo y laboratorio mediante un Análisis de Varianza (ANOVA) de medidas repetidas y test LSD Fischer. Estos resultados mostraron que los formulados 1 y 3 registraron un menor número de pulgones y momias comparados con los restantes tratamientos. Esta evidencia indicaría que estos formulados repelen pulgones y parasitoides, sin generar la letalidad que producen los insecticidas de amplio espectro.

Palabras clave: pulgones; extractos; aceites esenciales; parasitoides.

\section{INTRODUCTION}

In the Province of Entre Rios, Argentina, the peach aphid Myzus persicae and the cotton aphid Aphis gossypii have easily settled in greenhouse pepper production in response to optimal environmental conditions for their development.-The rapid increase of these populations gives rise to two types of damage: (1) direct damage as a result of sap feeding by adults and nymphs (Jarošvá et al., 2016) and (2) indirect damage due to the development of sooty mold - commonly known as "fumagina"-, which grows as a consequence of the carbohydrates excreted by nymphs and adults (SENASICA, 2014).

Although this substance causes considerable indirect damage because it weakens the plant and decreases its photosynthetic rates (Santos et al., 2013), the damage caused by the transmission of diseases by aphids, as vectors of diverse viruses in different crops, is even worse (Blackman and Eastop, 2017). Since only few studies related to significant pest management tools enhancing the conservation of natural enemies have been found, it was decided to study one specific tool in greenhouse pepper crops in the city of Concordia, Provincia de Entre
Ríos. Thus, a survey of a variety of natural enemies prior to the first stage of this research has been required. The species identified were Aphidius colemani (Viereck), Diaeretella rapae (Mc intosh), Praon Volucre (Holiday), Aphelinus abdominales (Dalman) (Hymenoptera Aphelinidae) and Praon volucre (Hymenoptera: Braconidae), as parasitoids of $M$. persicae and A. gossypii in the city of Concordia R. Paz, (personal communication, april 4, 2017) Currently, the use of synthetic pesticides is the usual method to control this pest; however, this strategy is not only inefficient (Bass et al., 2014) in horticultural crops, but also harmful for both the environment and human life (Costa, 2018). As a result, botanical insecticides deriving from EOs and Es - with various active compounds (secondary metabolites) - may offer a suitable alternative to chemical pesticides (Villaverde et al., 2014).

EOs are complex mixtures of diverse natural substances, for instance, monoterpenes, sesquiterpenes, phenols, oxides, ethers, alcohols, esters, aldehydes and ketones. However, most of these mixtures contain two or three main chemical components classified under two chemical groups such as terpenoids (monoterpenes and sesquiterpenes) and 
phenylpropanoid compounds (Asbahani et al., 2015), which - according to their combinations - may be biologically active to act synergistically as bactericides, fungicides, and insecticides (Tak and Isman, 2017). These components, which are part of EOs, enhance the crop protection since they act as a deterrent against feeding and adult oviposition that leads to an acute toxicity and the interruption of the developmental stages of these insects (Molina, 2001).

Therefore, these components provide an interesting alternative control that decomposes easily in the environment and is safer compared to synthetic pesticides (Pavela and Benelli, 2016). This research aimed to determine the efficiency of three botanical formulations for the management of $A$. gossypii and $M$. persicae and their effect on the parasitoid population in greenhouse pepper crops.

\section{MATERIALS AND METHODS}

This research was carried out in a greenhouse located in a horticultural section of the Argentine Agricultural Experiment Station (EEA) of the National Institute for Agricultural Technology (INTA) of the city of Concordia, Province of Entre Rios (Argentina), located at $31^{\circ} 22^{\prime} 22.16^{\prime \prime S}$; 58 ${ }^{\circ} 7^{\prime} 5.42^{\prime \prime} \mathrm{W} ; 396$ (metres above sea level) GPS coordinates. In March 28, 2016, the sweet pepper (Capsicum annum L.), ZEN F1 commercial hybrid (Clause) was transplanted in biosolarized soils within a plantation area of 1.20 metres between rows and 0.40 metres between plants. The plants were placed in a trellis structure and after one week, they were nourished with Nutrire Plus $^{\circledR}$ fertilizer at a rate of 3 litres $/ 100 \mathrm{~m}^{2} /$ on a weekly basis.

Three formulations derived from EOs and Es, an adjuvant and one control (Table 1 ).

Table 1. Treatments assessed for pest management.

\begin{tabular}{|c|c|c|c|}
\hline Product & Composition (\%) & Dosage & Application \\
\hline Formulation 1 & $\begin{array}{l}\text { AEs (Azadirachta indica A. juss.) 32\%, (Cinnamomun } \\
\text { verum J.Presl) 24\%, (Tagetes erecta L.) 8\%, (Origanum } \\
\text { vulgare L.) 4\%, and (Syzygium aromaticum L.) 2\%. }\end{array}$ & $5 \mathrm{ml} / \mathrm{L}$ water & \multirow{5}{*}{$\begin{array}{l}\text { On the aerial part of } \\
\text { the plant }\end{array}$} \\
\hline Formulation 2 & $\begin{array}{l}\text { AE (Allium sativum L.) } 30 \% \text { and EP (C. verum J.Presl) } \\
30 \%\end{array}$ & $5 \mathrm{ml} / \mathrm{L}$ water & \\
\hline Formulation 3 & $\begin{array}{l}\text { AE (A. indica L.) 70\%, EPs (A. sativum L.) } 25 \% \text { and } \\
\text { (Ruta graveolans L.) } 5 \% \text {. }\end{array}$ & $5 \mathrm{ml} / \mathrm{L}$ water & \\
\hline Lecithin & Soybean lecithin-based adjuvant (Lecithin Max $^{\circledR}$ ) & $2 \mathrm{ml} / \mathrm{L}$ water & \\
\hline Control & Water spray & & \\
\hline
\end{tabular}


These treatments were sprayed directly into the foliage at sunset - low intensity of sunlightand during the crop cycle with an interval time of 7-10 days from April to November, 2016, using a 20 litre symmetrical backpack sprayer (Guarany ${ }^{\odot}$ brand) equipped with a cone nozzle. Botanical products easily decompose when exposed to high temperatures, ultraviolet light and evaporation. Therefore, during the application -including the control treatmenta dose of $0.2 \%$ of soybean lecithin adjuvant was added (Lecithin Max $^{\circledR}$ ) to enhance the adhesion, penetration, and anti-evaporation. This product was donated by the company named Fragaria S.R.L (Villa Cañas, Santa Fe, Argentina). Prior to the application of these treatments, a monitoring process was carried out on a weekly basis as from the $16^{\text {th }}$ day after the transplanting (DAT).

These monitoring inspections determined whether the aphids (Aphis gossypii (Glover), Myzus persicae (Sulzer) were found above the damage threshold (DT) or not with an average number higher than 8 (nymphs + adults) per leaf (Polack and Mitidieri, 2005). Then it was decided to apply a treatment with a biorational pesticide based on [NeemAzal$\mathrm{T} / \mathrm{S}^{\circledR}(0.4 \%$ azadirachtin)] combined with [Hydralene ${ }^{\circledR}(0.2 \%$ potassium oleate $\left.)\right]$ to avoid causing serious damage to the crop.

In order to carry out this research, five raised beds of $0.50 \mathrm{~m}$ wide and $28 \mathrm{~m}$ long were built. Each of them comprised 3 plots of land, where 15 plants were placed. The plots of land were separated by transition zones or borders made of 5 plants to be isolated. A total of 15 homogeneous plots of land were counted. A completely randomized design with 5 treatments and 3 repetitions was used for this trial (plots of land). The efficacy of these treatments related to the aphids and their parasitoids through botanical formulations was determined based on successive direct count (pepper leaves) to record the following variables: (a) the number of wingless adults and nymphs of aphids found on pepper leaves and (b) the number of parasitized aphids (mummies) on pepper leaves. In order to estimate the population density of aphids in pepper crops, the total number of aphids (wingless adults + nymphs) was observed on the underside of 4 leaves in the middle part of the plant out of 5 plants randomly selected in each plot. Additionally, 20 leaves with mummies were collected from each plot. Leaves from the middle part of the plant were randomly selected to directly count the number of mummies on each leaf. These mummies were observed in the laboratory through a stereostopic magnifier of 10 to 40X to obtain information about parasitism (Polack and Mitidieri, 2005).

Once the results were recorder, a mixed lineal model and a repeated measures ANOVA were applied. The treatment factor were considered the fixed effect and the monitoring date, the random effect. Considering that the response variable (number of aphids) did not fit a normal distribution, the square root transformation was applied. Since data exploration detected distint variability between sampling dates and treatments, the model included heterogeneous variances for different dates. In addition, LSD Fisher test was applied in order to compare the means of the treatments and a 5\% significance level $(\alpha=0.05)$ was set. In order to study the association between the number of aphids and the number of parasitized aphids per leaf, the Spearman rank correlation coefficient was used. The adjustment of model and the related hypothesis test were performed using the software InfoStat Profesional version 2014. 


\section{RESULTS AND DISCUSSION}

The aphid was the pest observed in these monitoring processes. Figure 1 illustrates the mean number of aphids (wingless adults + nymphs) per leaf on different monitoring dates for each treatment.

The aphids recorded were M. persicae and $A$. gossypii, found in the crop since March $31^{\text {st }}$, 2016. Prior to the trial, it was observed that the mean number of aphids/leaf count was above the damage threshold. That is, more than 8 aphids (nymphs + adults) per leaf in some plots of land in different treatments (Figure 1). This situation demanded a control treatment with neem and potassium soap. Since then, the subsequentsampling dates only showed a subtle increase in the population of aphids per leaf after the application of two treatments (lecithin and control) whereas the other treatments remained with a number of aphids significantly lower than the damage threshold. Closer to the sampling date of October $13^{\text {th }}$, the treatments (lecithin and control) recorded the highest number of the population of aphids. In the control treatment, the population exceeded the damage threshold (15.08 mean aphids per leaf), and in the second treatment, it yielded similar values (7.02 mean aphids per leaf). Under these circumstances, a biorational product needed to be applied. Subsequently, despite the fact that this application reduced the number of aphids per leaf, on the sampling date of October $17^{\text {th }}$, it was observed that the population in the control treatment increased again (5.17 mean aphids per leaf) as well as in the lecithin treatment (5.90 mean aphids per leaf), which was close to the damage threshold. However, in this case, it was decided not to apply any biorational product. On the subsequent sampling date of November $1^{\text {st }}$, it was observed that only in the control treatment the number of aphids increased to almost the damage threshold (5.62 mean aphids per leaf).

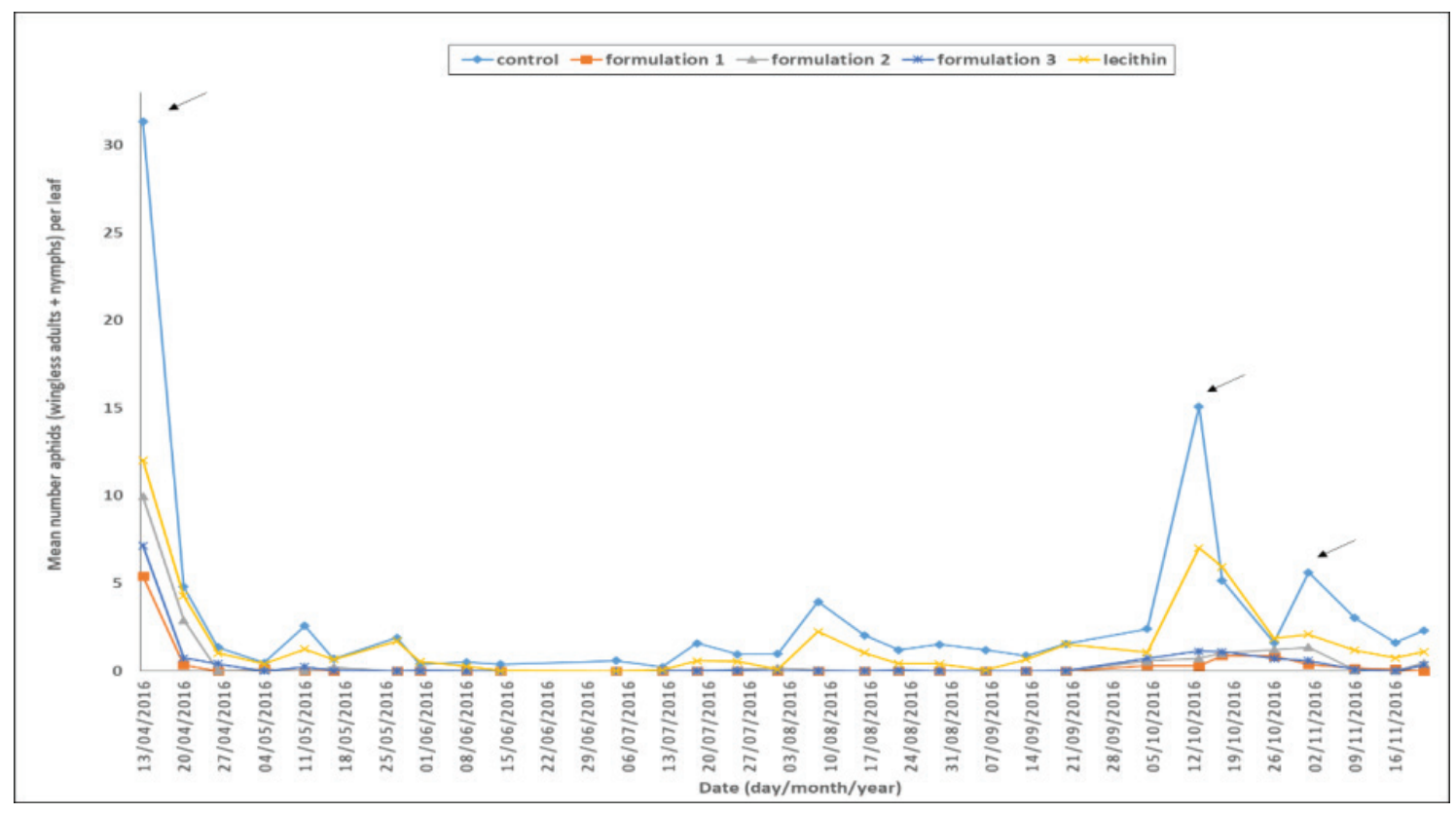

Figure 1. Aphids (nymphs + adults) per pepper leaf during the trial. The dates refer to the moments when a control treatment with biorational products was applied. 
Thus, a control treatment was applied again. It is worth mentioning that the products were applied to each plot of land on the same date during the whole period of the trial. Concerning the treatments, the formulations always kept the plants with an extremely low number of aphids per leaf. Fixed effect of treatments was significant $(\mathrm{p}<0.001)$, showing differences between mean number of aphids per treatment, which is clearly illustrated in Figure 1. Significant differences between means are shown in Figure 2A. The control treatment recorded the highest mean number of aphids during the period of the trial, followed by the lecithin and formulation 2. Finally, formulation 3 and formulation 1 showed a significant lower mean number of aphids.

In the trial, parasitoids $A$. colemani and $D$. rapae R. Paz, (personal communication, april 4, 2017) were identified. Regarding parasitism, it can be ascertained that a sparse population was found during the period of the trial because of its small number and low frequency of occurrence (Figure 3).
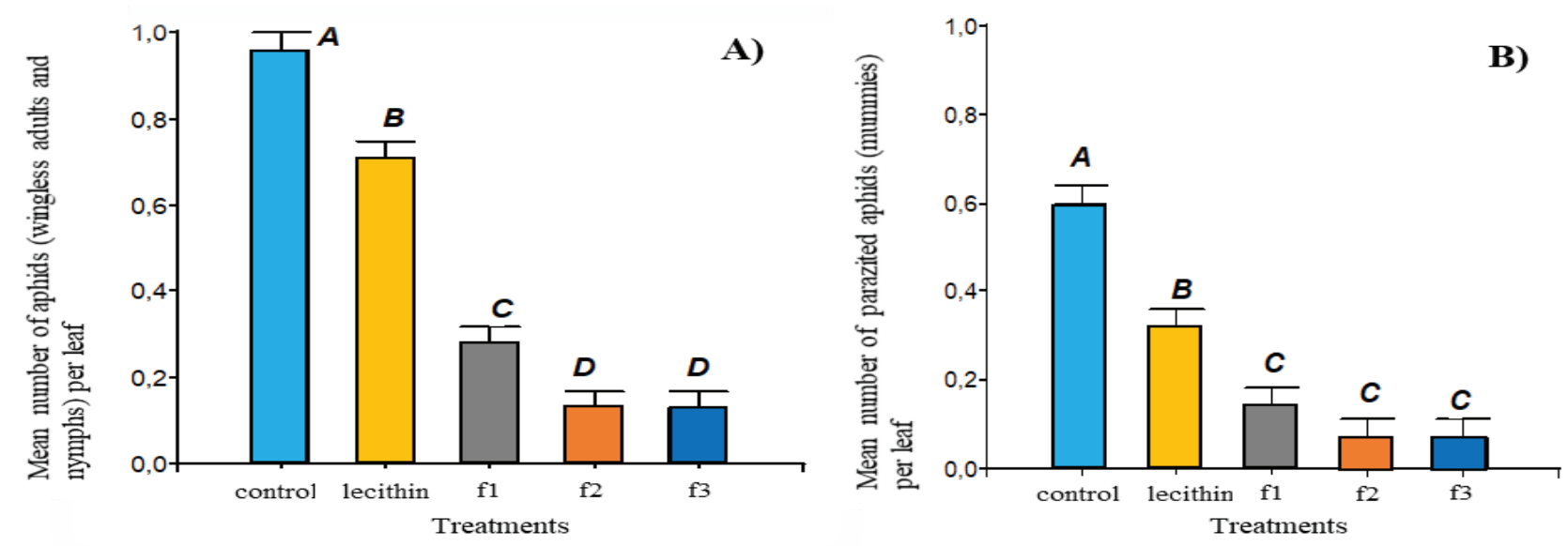

Figure 2. Estimated mean values of the square root of $\mathbf{A}$ ) number of aphids and $\mathbf{B}$ ) number of parasitized aphids per leaf in each treatment. Mean values with different letters indicate significant differences among the treatments (LSD, $\mathrm{p}<0.05$ ). 


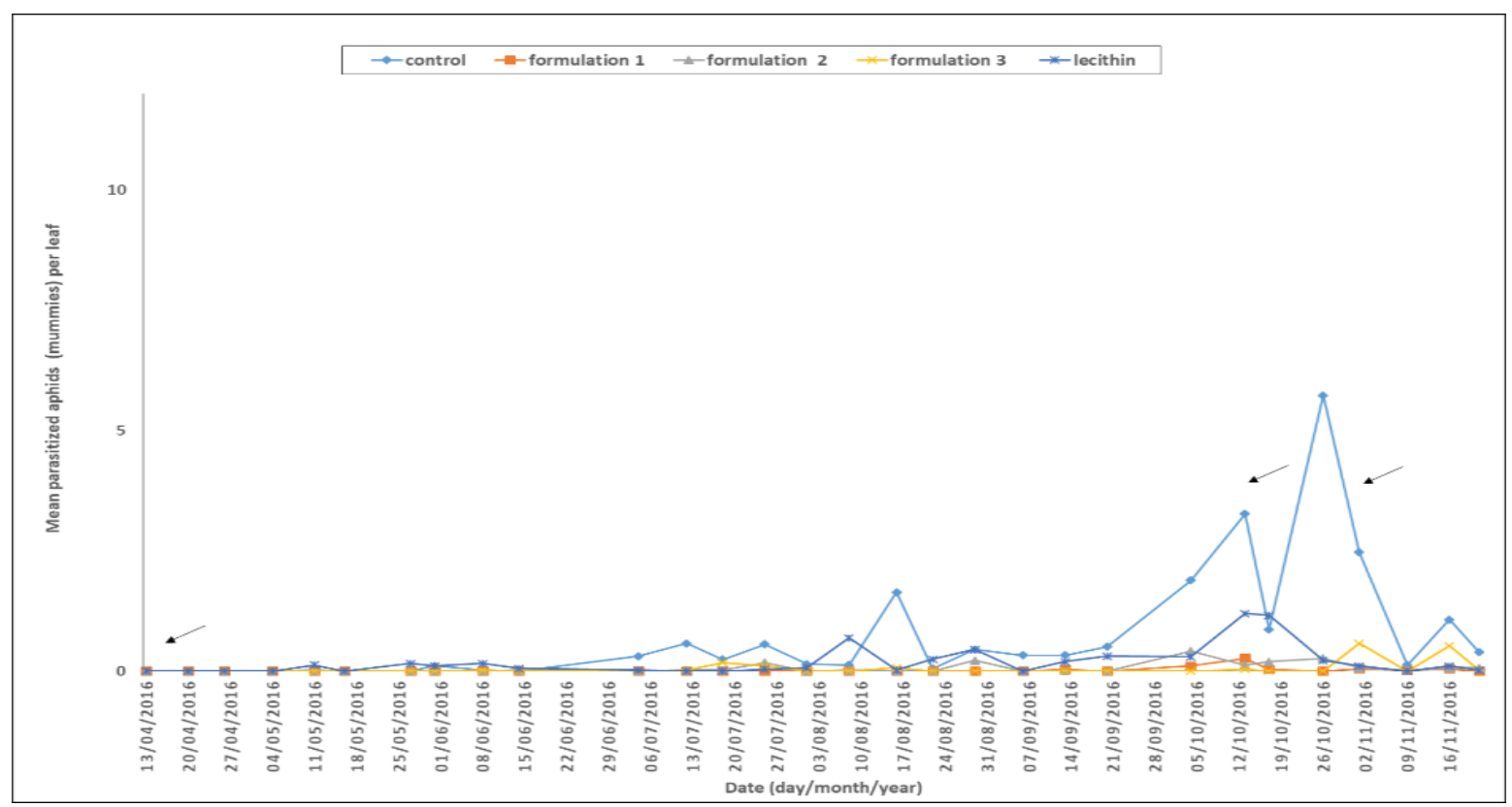

Figure 3. Parasitized aphids (mummies) per pepper leaf during the period of the trial. The date indicates the time when a control treatment with biorational products was applied.

In relation to the evolution of the population of aphids, the results observed in this study indicate that formulation 1 and 3 recorded a significantly lower mean number of aphids than the other treatments, as shown in Figure 1. This result was mainly the consequence of a remarkable repellent action, which could be confirmed by the absence of remains of dead aphids on leaves. On the other hand, it was seen that the plants treated with formulations derived from EOs constantly showed fewer aphids (adults and nymphs) compared to the control treatment, which suggests a repellent effect deriving from EOs.

Even though all EOs and Es are by-products of the plant metabolism, and plants use them to protect themselves from insects and mite pests which feed on them (Goyal et al., 2012), their natural components, in isolation or combined with other components, may have biological activity that causes varied effects such as contact insecticides, growth regulator, repellent, and anti-feedant activity (Mossa, 2016). Regarding the repellent activity, it is still very hard to identify the molecules that give rise to such effects as a result of natural active principles of EOs and Es (Isman, 2006). The application of formulation 1 composed of EOs of neem (Azadirachta indica A. Juss, Meliaceae), cinnamon (Cinnamomum verum J. Presl, Lauraceae), clove (Syzygium aromaticum L., Myrtaceae), oregano (Origanum vulgare L., Lamiaceae) and American marigold E (Tagetes erecta L., Asteraceae) showed a deterrent effect at the applied dose ( $5 \mathrm{ml} /$ litre of water), which might have resulted from the chemical components deriving from extracts and essential oils with repellent, anti-feedant, or insecticidal effects. These results were confirmed by studies conducted by Chaudhary et al. (2017), which indicated that one of the components of neem EO is azadirachtin, a tetranortriterpenoid 
that causes effects on insect pest, including aphids.

Among these effects, feeding suppression, growth failure, and fecundity problems in the peach aphid could be found (Sulzer). Regarding the second component of formulation 1, cinnamon EO, Cheng et al. (2009) demonstrated that the chemical components of EOs of leaves of six species of Cinnamomum possess a larvicidal effect on different mosquitoes (Aedes albopictus, Culex quinquefasciatus and Armigeres sulbatatus) and reported a significant mortality after $24 \mathrm{~h}$ and $48 \mathrm{~h}$. This effect is the result of the main component known as trans-cinnamaldehyde found in cinnamon EO (Prajapati et al., 2005). Other previous studies, which included transcinnamaldehyde derived from cinnamon EO made by Hilje (2001) affirmed that a minimum dose of $0.1 \%(\mathrm{v} / \mathrm{v}$ ) on Bemisia tabaci adults resulted in anti-feedant and oviposition deterrent effects. The third component of formulation 1 is clove E0, which has eugenol as its main component (Tian et al., 2015), and it is considered as an insecticide by Jumbo et al. (2014).

In addition, previous studies conducted in the laboratory by Isman (2000) revealed that the mixture of thymol and eugenol applied to leaves modified the behaviour of nymphs of the second developmental stage of the peach aphid, since it was observed that a rate lower than $50 \%$ of aphids fed on the plant whereas the other aphids walked or were dead. As regards oregano EO, the biological activity and chemical composition has been studied by Xie et al. (2019), who confirmed that the main phenolic monoterpenoid are carvacrol and thymol while other components can be found in less concentration such as $p$-cymen and $\gamma$ - terpinene. The concentrations of these various compounds depend on the area where this plant is cultivated and harvested (Faleiro et al., 2003).

Additionally, recent studies made by Szczepanik et al. (2018) showed an effective control on the insects which affect stored products. Zhang etal. (2016) observed that the carvacrol compound had the most toxic effect on Drosophila melanogaster, and according to Park et al. (2016), especially on larvae and adults of fruit fly (Drosophila suzukii). Finally, formulation 1 contained American marigold EO (Tagetes erecta L., Asteraceae). Its flowers and leaves have a biocidal effect due to a wide array of secondary metabolites, including acyclic,monocyclicand bicyclic monoterpenes, sesquiterpenes, flavonoids, carotenoids and thiophenoes (Wanzala and Ogoma, 2013). The group of terpenoids includes Z- $\beta$-ocimene and dihydrotagetone with nematicide activity in the egg and juveniles of nematode (Meloidogyne incognita). It should be noted that dihydrotagetone is the highest toxic component (Adekunle et al., 2007). In addition, Daedouri et al. (2019) determined that ethyl alcohol solutions of Tagetes minuta have a repellent and insecticidal effects as a result of their components deriving from bithienyl and Alpha-terthienyl. Therefore, the reduce number of aphids alive on pepper leaves resulted from the repellent effect of the natural substances applied on these plants.

The application of formulation 3 composed of EO of neem (A. indica), E of garlic (Allium sativum L. Amaryllidaceae), and $\mathrm{E}$ of rue (Ruta graveolans L., Rutaceae) gave rise to a repellent effect when a dose of $5 \mathrm{ml} /$ litre was applied. This effect was thought to be the result of various chemical components which are part of these Es and EOs. The E of garlic provides a high insecticidal potential (Awais 
et al.,2014) due to its main sulfur components of higher biological activity such as allicin and diallyl trisulfide (Hrbek et al., 2018), which are produced by cell decomposition (Awais et al., 2014). In addition, the $\mathrm{E}$ of garlic was studied by Ho et al. (1996), who concluded that it produces a behaviour change in aphids Myzus persicae at the time they settle on the host plant due to its anti-feedant effect resulting in the death of aphids. Barati et al. (2014) showed that the E of garlic enhanced the reduction of oviposition of white flies in 56.6 and $56.5 \%$, respectively, compared to the untreated controls. In other studies, Prowse et al. (2006) observed that the sulfur components of the $\mathrm{E}$ of garlic after contact with soil decompose, and consequently, are hydrolized resulting in a variety of isothiocyanates offering an insecticidal, nematicidal, and fungicidal effect.

Regarding the last component of this formulation, rue E, as well as other plants, it has active principles such as glucoside, flavonoid (rutin), and inulin (Haddouchi et al., 2013), which have a repellent, nematicidal (larvicidal and adulticidal) as well as an insecticidal effect on various pests (Tavares et al., 2013). In summary, the treatments formulation 1 and 3 displayed the same behaviour and recorded alive aphids on pepper leaves below the damage threshold. With respect to mummies per leaf, it could be observed that the mean of parasitized aphids significantly differed among treatments $(\mathrm{p}<0.001)$. In plants in the control treatment, the count of aphids per leaf was significantly higher than the other treatments (Figure 2B). On the other hand, the lecithin treatment revealed a significantly higher mean of mummies than that observed in any of the other formulations. In relation to the control treatment (water spray), no considerable repellent effect on aphids or their parasitoids on leaves was observed; therefore, a higher number of mummies was noticed.

These results correlate with those obtained by Reddy and Guerreo (2004), who studied volatile compounds emitted by plants injured by herbivore insects which promote the attraction of one or more specific natural enemies as a defence mechanism. Similarly, in the soy lecithin treatment, a number of aphids and mummies higher than the other treatments was reported; however, this number was lower than the one collected in the control treatment. These results might be attributed to the quality, as mentioned by Orthoefer (1980), of the soylecithin to enhance the dispersing properties in cold water that form stable emulsions. On the other hand, it should be noted that this product added to ethyl lactate, propylenglicol, or carbitols can be used as insecticide, leather dyeing and tanning according to Jordan (1939). Thus, it could be inferred that the application of lecithin in the plots of land might have produced repellent effects, at a certain extent, on parasitoids resulting in a search behavior change among aphid colonies. Lastly, it should be mentioned that during the period of this trial, a low mean number of parasitized aphids was recorded.

\section{CONCLUSIONS}

The results of this trial showed that formulation 1 and formulation 3 have kept the number of aphids below the damagethreshold, and in every treatment - either before or after the applications - aphid parasitoids spontaneously occurred. Notwithstanding this, it should be noted that the control and the lecithin treatment reported the highest number of mummies due to a higher number 
of aphids. Therefore, we can conclude that the applications of different formulations based on botanical components, EOs and Es could be an interesting alternative to be applied in an integrated pest management (IPM) in greenhouse pepper crops. The use of these formulations derived from EOs and Es would considerably reduce the application of synthetic pesticides and allow an efficient aphid control resulting in a lesser impact on entomological fauna due to few residual effects, and hence promoting the development of a commercial sustainable product that would benefit the environment tremendously.

Conflict of interests: The authors declare that there is no conflict of interest.

\section{BIBLIOGRAPHIC REFERENCES}

Adekunle, 0.; Acharya, R.; Singh, B. (2007). Toxicity of pure compounds isolated from Tagetes minuta oil to Meloidogyne incognita. Australasian Plant Disease. 2:101- 104.

Asbahani, A. E.; Miladi, K.; Badri, W.; Sala, M.; Addi, E. H. A.; Casabianca, H.; Mousadik, A. E.; Hartmann, D.; Jilale, A.; Renaud, F.N.R. (2015). Essentialoils: From extraction to encapsulation. International Journal Pharmaceutics. 483:220243. doi: 10.1016/j.ijpharm.2014.12.069

Awais, M. M.; Akhtar, M.; Iqbal, Z.; Muhammad, F. (2014). Saccharum officinarum derived mid molecular mass glycoproteins as native BRMs in chickens. Pakistan Journal of Life and Society Sciences. 11: 200-207.

Barati, R.; Golmohammadi, G.; Ghajarie, H.; Zarabi, M.; Mansouri, R. (2014). Efficiency of some herbal pesticides on reproductive parameters of silverleaf whitefly, Bemisia tabaci (Gennadius) (Hemiptera: Aleyrodidae). Archives of Phytopathology and Plant Protection. 47: 212221. doi: 10.1080/03235408.2013.807035.
Bass, C.; Puinean, A. M.; Zimmer, C. T.; Denholm, I.; Field, L. M.; Foster, S. P.; Gutbrod, O.; Nauen, R.; Slater, R.; Williamson, M.S. (2014). The evolution of insecticide resistance in the peach potato aphid, Myzus persicae. Insect Biochemistry and Molecular Biology. 51:41-51. doi: 10.1016/j.ibmb.2014.05.003

Blackman, R. K.; Eastop, V. F. (2017). Taxonomic issues. In: van Emden $\mathrm{H}$, Harrington R (eds.). Aphids as crop pests. $2^{\text {nd }}$ edn. Wallingford, UK: CABI Publishing.

Chaudhary, S.; Kanwar, R. K.; Sehgal, A.; Cahill, D. M.; Barrow, C. J.; Sehgal, R.; Kanwar, J. R. (2017). Progress on Azadirachta indica based Biopesticides in replacing synthetic Toxic Pesticides. Frontiers in Plant Science. 8: 610. doi: https://doi.org/10.3389/fpls.2017.00610

Cheng, S.; Liu, J.; Han C.; Hsui, Y.; Chen W.; Chang, S. (2009). Insecticidal activities of leaf essential oils from Cinnamomum osmophleum against three mosquito species. Bioresource Technology. 100(1): 457-464. doi: 10.1016/j. biortech.2008.02.030

Costa, L.G.(2018). Organophosphorus compounds at 80: some old and new issues. Toxicological Sciences. 162: 24-35. doi.org/10.1093/toxsci/ kfx266

Daedouri, T.; Gautier, H.; Ben Issa, R.; Costagliola, G.; Gomez, L. (2019). Repellence of Myzus persicae (Sulzer): evidence of two modes of action of volátiles from selected living aromatic plants. Pest Management Science. 75: 15711584. doi: https://doi.org/10.1002/ps.5271

Faleiro, M. L; Miguel, M. G.; Ladeiro, F.; Venâncio, F.; Tavares, R.; Brito, J.C.; Figueiredo, A. C.; Barroso, J. G.; Pedro, L. G. (2003). Antimicrobial activity of essential oils isolated from Portuguese endemic species of Thymus. Letters and Applied Microbiology. 36(1): 35-40. doi: https://doi. org/10.1046/j.1472-765X.2003.01259.x

Goyal, S.; Lambert, C.; Cluzet, S.; Merillon, J. M.; Ramawat, K. G. (2012). Secundary metabolites and plant defence. Progress in Biological Control. 12: 109-138. doi: https://doi. org/10.1007/978-94-007-1933-0_5 
Haddouchi, F.; Chaouche, T. M.; Zaouli, Y.; Ksouri, R.; Attou, A.; Benmansour, A. (2013). Chemical composition and antimicrobial activity of essential oils from four Ruta species growing in Algeria. Food Chemistry. 141(1): 253-258. doi: 10.1016/j.foodchem.2013.03.007

Hrbek, V.; Rektorisova, M.; Chmelarova, H.; Ovesna, J. (2018). Authenticity assessment of garlic using a metabolomic approach based on high resolution mass spectrometry. Journal of Food Composition and Analysis. 67: 19-28. doi: https://doi.org/10.1016/j.jfca.2017.12.020

Hilje, L. (2001). Avances hacia el manejo sostenible del complejo Bemisia tabaci-geminivirus en tomate, en Costa Rica. Manejo integrado de Plagas. 61:70-81.

Ho, S.H.; Koh, L.; Ma, Y.; Huang, Y.; Sim, K.I. (1996). The oil of garlic, Allium sativum L. (Amaryllidaceae), as a potential grain protectant against Tribolium castaneum (Herbst) and Sitophilus zeamais Motsch. Postharvest Biology and Technology. 9: 41-48. doi: 10.1016/0925-5214(96)00018-X

Isman, M.B. (2000). Plant essential oils for pest and disease management. Crop Protection. 19: 603-608. doi: https://doi.org/10.1111/ j.1365-2672.2012.05270.x

Isman, M. B. (2006). Botanical insecticides, deterrents and repellents in modernagriculture and an increasingly regulated world. Annual Review of Entomology. 51: 45-66. doi: 10.1146/ annurev.ento.51.110104.151146

InfoStat, (2014). InfoStat versión 2014. Argentina: Grupo InfoStat, FCA, Universidad Nacional de Córdoba. 200p.

Jarošvá, J.; Beoni, E.; Kundu, J. K. (2016). Barley yellow dwarf virus resistance in cereals: approaches, strategies and prospects. Field Crops Research. 198: 200-214. doi: https://doi. org/10.1016/j.fcr.2016.08.030

Jordan, S. (1939). Water Dispersible Lecithin. U.S. Patent. 2, 296, 933. Recovered from https:// patents.google.com/patent/US2193873A/en
Jumbo, L. O. V.; Faroni, L. R. A.; Oliveira, E. E.; Pimentel, M.A.; Silva, G. N. (2014) Potential use of clove and cinnamon essential oils to control the bean weevil, Acanthoscelides obtectus Say, in small storage units. Industrial Crops and Products. 56: 27-34. doi: https://doi. org/10.1016/j.indcrop.2014.02.038

Molina, N. (2001). Uso de extractos botánicos en control de plagas y enfermedades. Revista Manejo Integrado. (59): 76-77.

Mossa, A. H. (2016). Green Pesticides: Essential Oils as Biopesticides in Insect-pest Management. Journal of Environmental Science and Technology. 9(5): 354-378. doi: 10.3923/ jest.2016.354.378

Orthoefer, F. (1980). Cold Later Dispersible Lecithin Concentrates. U.S. Patent 4,200,551. Recovered from https://patents.google.com/ patent/US4200551A/en

Pavela, R.; Benelli, G. (2016). Essential oils as eco-friendly biopesticides? Challenges and constraints. Trends Plant Science. 12: 10001007. doi: 10.1111/j.1461-9555.2006.00273.x

Park, C. G.; Jang, M.; Yoon, K. A.; Kim, J. (2016). Insecticidal and acetylcholinesterase inhibitory activities of Lamiaceae plant essential oils and their major components against Drosophila suzukii (Diptera: Drosophilidae). Industrial Crops and Products. 89: 507-513. doi: 10.1016/j.indcrop.2016.06.008

Polack, L.; Mitidieri, M. (2005). Producción de tomate diferenciado. Protocolo preliminar de manejo integrado de plagas y enfermedades. EEA San Pedro, INTA. Recovered from https://inta. gob.ar/documentos/produccion-de-tomatediferenciado-protocolo-preliminar-de-manejointegrado-de-plagas-y-enfermedades

Prajapati, V.; Tripathi, A. K.; Aggarwal, K. K.; Khanuja, S.P.S. (2005). Insecticidal, repellent and oviposition-deterrent activity of selected essential oils against Anopheles stephensi, Aedes aegypti and Culex quinquefasciatus. Bioresource Technology. 96(16): 1749-1757. doi: 10.1016/j.biortech.2005.01.007 
Prowse, G. M.; Galloway T. S.; Foggo, A. (2006). Insecticidal activity of garlic juice in two dipteran pests. Agricultural and Forest Entomology. 8(1):1-6. doi: https://doi. org/10.1111/j.1461-9555.2006.00273.x

Reddy, G.; Guerrero, A. (2004). Interactions of insect pheromones and plant semiochemicals. TrendsPlantScience.9(5):253-261.doi:https:// doi.org/10.1016/j.tplants.2004.03.009

Santos, S. A. P.; Santos, C.; Silva, S.; Pinto, G.; Torres, L. M.; Nogueria, A.J.A. (2013). Effect of sooty mold on fluorescence and gas Exchange properties of olive tree. Turkish Journal of Biology. 37(5): 620-628. doi: 10.3906/biy1301-81

Szczepanik, M.; Walczak, M.; Zawitowska, B.; Michalska-Sionkowska, M.; Szumny, A.; Wawrze'nczyk, C.; Brzezinska, M.S. (2018). Chemical composition, antimicrobial activity and insecticidal activity against the lesser mealworm Alphitobius diaperinus (panzer) (Coleoptera: Tenebrionidae) of Origanum vulgare L. ssp. Hirtum (link) and Artemisia dracunlus L. essential oils. Journal of the Science of Food and Agriculture. 98: 767-774. doi: 10.1002/jsfa.8524

SENASICA - Servicio Nacional de Sanidad, Inocuidad y Calidad Agroalimentaria. (2014). Pulgón amarillo Melanaphis sacchari (Zehntner). Dirección General de Sanidad Vegetal. Ficha técnica, $\mathrm{N}^{\circ}$ 43. México, D.F: Centro Nacional de Referencia Fitosanitaria.15p.

Tak, J. H.; Isman, M. B. (2017). Penetrationenhacement underlies synergy of plant: essential oil terpenoids as insecticides in the cabbage looper. Trichoplusia ni. Scientific Reports. 7:72432. doi: https://doi. org/10.1038/srep42432

Tavares, W. D.; Freitas, S. D.; Grazziotti, G. H.; Parente, L. M. L.; Lião, L. M.; Zanuncio, J. C. (2013). Ar-turmerone from Curcuma longa (Zingiberacear) rhizomes and effects on Sitophilus zeamais (Coleoptera: Curculionidae) and Spodoptera frugiperda (Lepidoptera:
Noctuidae). Industrial Crops Products, 46: 158-164. doi: 10.1016/j.indcrop.2013.01.023

Tian, B. L.; Liu, Q. Z.; Liu, Z. L.; Li, P.; Wang, J. W. (2015). Insecticidal potencial of clove essential oil and its constituents on Cacopsylla chinensis (Hemiptera: Psyllidae) in laboratory and field. Journal of Economic Entomology. 108(3): 957961. doi: https://doi.org/10.1093/jee/tov075

Villaverde, J. J.; Sevilla, B.; Sandín, P.; López, C.; Alonso, J. L. (2014). Biopesticides in the framework of the European Pesticide Regulation (EC) $\mathrm{N}^{\circ}$. 1107/2009. Pest Management Science. 70(1): 2-5. doi: https:// doi.org/10.1002/ps.3663

Xie, Y. J.; Huang, Q. Q.; Rao, Y. Q.; Hong, l.; Zhang, D. Y. (2019). Efficacy of Origanum vulgare essential oil and carvacrol against the housefly, Musca domestica L. (Diptera: Muscidae). Environmental Science and Pollution Research. 26: 23824-23831. doi: https://doi. org/10.1007/s11356-019-05671-4

Wanzala, W.; Ogoma, S. B. (2013). Chemical composition and mosquito repellency of essential oil of Tagetes minuta from the Southern slopes of Mount Elgon in Western Kenya. Journal of Essential Oil Bearing Plants. 16(2): 216-232. doi: https://doi.org/10.1080 /0972060X.2013.793975

Zhang, Z. L.; Yang, T.; Zhang, Y. K.; Wang, L. H.; Xie, Y. J. (2016). Fumigant toxicity of monoterpenes against fruitfly, Drosophila melanogaster. Industrial Crops and Products. 81:147-151. doi: https://doi.org/10.1016/j. indcrop.2015.11.076 